\title{
Carbohydrate Supply as a Critical Factor for Citrus Fruit Development and Productivity
}

\author{
Eliezer E. Goldschmidt \\ The Kennedy-Leigh Centre for Horticultural Research, Faculty of Agricultural, Food, and Environmental Quality \\ Sciences, The Hebrew University of Jerusalem, Rehovot 76100, Israel
}

Productivity is the final outcome of a long chain of developmental events. The reproductive processes leading to cropping in a fruit tree may be analyzed at two distinct levels: 1) the reproductive unit, single organ level, and 2) the multi-organ fruit population, tree level. (The orchard, with its tree population, represents a still higher organizational level.) Although a complete "failure" at the organ level precludes crop formation altogether, both types of analysis are biologically meaningful and differ in many respects. Analysis at the organ level will focus on cellular and biochemical processes. Analysis at the tree level will emphasize quantitative aspects, employing statistical and modeling approaches. Taking "fruit set" as an example, for the individual fruit it is an "all-or-none" event, governed by hormonal and biochemical systems. However, when the fruit population of an entire tree is considered, the rate of fruit set assumes a quantitative significance.

The carbohydrate economy of plants, more frequently referred to as source-sink relationships, has received considerable attention in recent years, and important biochemical and regulatory aspects have been elucidated. However, such research has been conducted mainly with model plants and with a few annual crop plants. Our knowledge and understanding of these processes in fruit trees, in general, and citrus, in particular, are still very fragmentary. Carbohydrate economy may be more problematic in this respect than other research areas, because of considerable variability among plant genera and the existence of several biochemical alternatives.

The source-sink physiology of citrus as related to fruit growth and productivity has been investigated extensively in the last decades, mainly at the quantitative tree level. Certain cellular and biochemical carbohydrate systems have been examined at the organ level, mainly in relation to fruit development and maturation. Most of this research has been reviewed by Goldschmidt and Koch (1996).

The present article concentrates on specific aspects of citrus' source-sink relationships that deserve further discussion, and indicates directions for future research.

\section{THE EVERGREEN FRAMEWORK}

The division of fruit trees into deciduous and evergreens has farreaching developmental and physiological implications. These two groups have different environmental adaptations and survival strategies, some of which are intimately related to the management of carbohydrate resources. The carbohydrate economy of citrus should be studied and interpreted in the context of its evergreen nature, and comparisons with other subtropical, evergreen fruit crops (e.g., avocado, mango) may be instructive. The evergreen habit has important consequences with regard to the role played by the reserve carbohydrates during spring. For bud burst and early spring growth, deciduous trees are totally dependent upon carbohydrate reserves stored in perennial, woody tree organs (Loescher et al., 1990). In evergreens, the uninterrupted presence of leaves, which may be somewhat old but still

Received for publication 6 Oct. 1998. Accepted for publication 17 Nov. 1998. This research was supported by funds from the Israeli Ministry of Agriculture. We thank A. Bustan for discussions and criticism during the preparation of the manuscript. The valuable comments and suggestions for improvement of the manuscript by F.G. Dennis Jr., Y. Erner, J.L. Guardiola, Karen E. Koch, J. Maas, and J.P. Syvertsen are gratefully acknowledged.The cost of publishing this paper was defrayed in part by the payment of page charges. Under postal regulations, this paper therefore must be hereby marked advertisement solely to indicate this fact. photosynthetically functional, partly alleviates the dependence upon carbohydrate reserves, Nevertheless, even in citrus, the spring flush, floral development, anthesis, and fruit set demand large amounts of energy that cannot be furnished by current photosynthesis and must be obtained from tree reserves (Bustan and Goldschmidt, 1998).

The decline in carbohydrate levels throughout the flowering and fruit set period (Gonzalez-Ferrer et al., 1984; Hilgeman et al., 1967; Jones and Steinacker, 1951), which is accentuated by heavy flowering (Garcia-Luis et al., 1988), indicates that reserve carbohydrates are indeed utilized to sustain the early stages of reproductive development (Shimizu et al., 1978). Similar trends in carbohydrate cycling have been reported for avocado (Scholefield et al., 1985). Experiments with labeled $\mathrm{CO}_{2}$ indicated that reserve carbohydrates were utilized mainly to support reproductive development, while photosynthesis from mature leaves supplied the needs of vegetative growth (Akao et al., 1981).

Subtropical evergreen trees generally have lower net photosynthetic rates than deciduous, temperate species (Kriedemann, 1971; Larcher, 1980). On the other hand, evergreens may be photosynthetically active all year long, whereas deciduous species have only the summer months for photosynthetic activity. The annual course of photosynthesis in evergreen and deciduous fruit trees is schematically presented in Fig. 1. Although the reasons underlying the difference in photosynthetic rates between deciduous and evergreen fruit trees are not fully understood, there seems to be a link between the longer life span of leaves in evergreen species [as also reflected in leaf structure (Syvertsen et al., 1995)] and their lower photosynthetic rates (Chabot and Hicks, 1982). At the evolutionary level, it may be proposed that deciduous species have developed higher photosynthetic rates to compensate for the restricted period of photosynthetic activity.

The situation may actually be more complex. Assimilation rates of 4 to $10 \mu \mathrm{mol} \cdot \mathrm{m}^{-2} \cdot \mathrm{s}^{-1}$ of $\mathrm{CO}_{2}$ are attained in most citrus field experiments but higher rates are frequently obtained in the greenhouse (Syvertsen and Lloyd, 1994). The subtropical avocado and mango have been reported to have low photosynthetic rates, but improved rates were recently obtained under optimal conditions (Schaffer et al., 1994; Whiley and Schaffer, 1994). Whiley et al. (1999) suggest that orchard trees may frequently be suffering from root restriction, which limits their photosynthetic capacity. Similar views have been expressed with regard to citrus by Idso and Kimball (1994). However, comparable conditions may prevail in deciduous orchards, and the general validity of this hypothesis requires broader confirmation.

Another aspect that deserves attention is the significance of winter photosynthesis for evergreen tree crops. In numerous Mediterranean and maritime subtropical areas, cool winter temperatures and cloudiness supposedly minimize photosynthetic gains. In other subtropical areas, however, there are many warm, sunny days during winter. In recent work in Florida (Syvertsen et al., 1997) and Israel (Bustan et al., unpublished data), relatively high photosynthetic rates were recorded for citrus during winter. The large year-to-year variability in pounds solids production by 'Valencia' oranges in Florida has recently been correlated with winter temperatures, which presumably reflect photosynthetic activity (Albrigo, 1997). This aspect of citrus' carbohydrate economy should be further investigated.

\section{CRITICAL STAGES}

Conceptual analysis of the processes controlling citrus yield has led to the identification of three critical "points of decision": flower bud differentiation, fruit set, and fruit enlargement (Goldschmidt and 


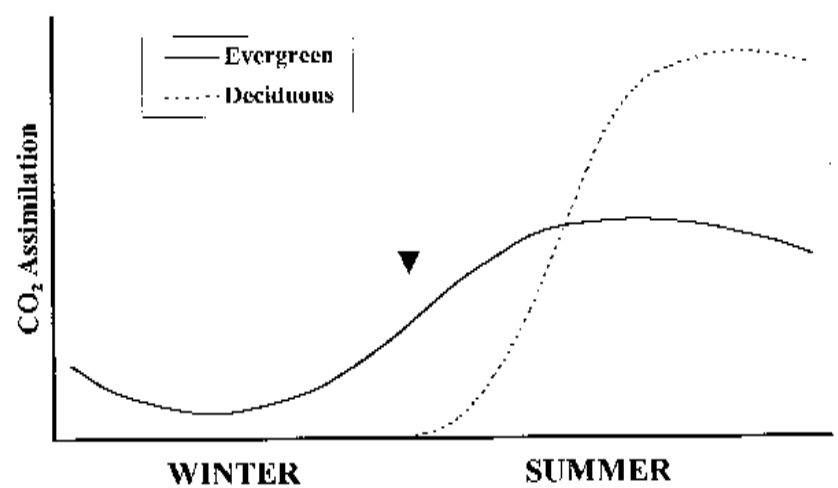

Fig. 1. Schematic annual course of photosynthetic activity in evergreen and deciduous fruit trees. The arrow marks the onset of spring growth in deciduous fruit trees.

Monselise, 1978). At the tree level, all three decisions assume a quantitative meaning and one may wonder what are the controlling factors. In the present article, we will examine the potential regulatory significance of carbohydrate levels for decisions made during these developmental stages. The evidence is rather indirect, however, based mainly on effects of the horticultural source-sink manipulation agrotechniques, girdling, and fruit thinning. Whereas girdling eliminates the effects of alternative, competing sinks (e.g., the root system or, in the case of limb girdling, other limbs), and fruit thinning reduces fruit-fruit competition, both techniques increase the amount of photosynthate available to the surviving reproductive organs. Thus, positive effects of girdling on flower bud differentiation and fruit set may be taken as evidence for the critical role of carbohydrates in these developmental processes. Likewise, the increased growth of the remaining fruit following fruit thinning suggests that the amount of photosynthate available limits fruit growth. And, yet, it must be borne in mind that this type of evidence is indirect and might be open to alternative interpretations. Girdling, in particular, has been shown to affect the hormonal balance of fruit trees (Cutting and Lyne, 1993; Dann et al., 1985; Wallerstein et al., 1973).

\section{FLOWER FORMATION}

Autumn girdling intensifies flowering in the subsequent spring (Cohen, 1981), causing a shift towards the pure, leafless, generative inflorescences and increasing floral numbers (Goldschmidt et al., 1985). Trunk girdling may cause root starvation and offset the hormonal balance of roots (Cutting and Lyne, 1993), but girdling also increases flowering when performed on small branches, precluding any effect on the root system (Goldschmidt et al., 1985). In most studies, girdling-induced promotion of flowering has been correlated with accumulation of carbohydrates. However, girdling increased flowering even when no increase in leaf or twig carbohydrate levels could be detected (Garcia-Luis et al., 1995), although changes in carbohydrates may still have occurred within bud tissues.

In alternate bearing cultivars, no flowers are formed following a heavy crop, "on" year, presumably due to the severe depletion of carbohydrates from all tree organs. Indeed, defruiting by midsummer during an "on" year partly restored carbohydrate levels and allowed the formation of some flowers (Goldschmidt and Golomb, 1982).

Although the intensity of flowering of young, container-grown 'Minneola' trees was proportional to their exposure to cold temperatures, it was not correlated with leaf, twig, or root starch levels. (Goldschmidt et al., 1985). Evidently, carbohydrate levels are not the sole factor limiting citrus flowering. Hormonal regulation by endogenous gibberellins apparently plays a critical role (Goldschmidt et al., 1997; Spiegel-Roy and Goldschmidt, 1996). Collective evidence indicates, nevertheless, that a minimum, threshold level of carbohydrates is a prerequisite for flower bud differentiation in citrus.

\section{FRUIT SET}

Fruit set comprises a series of cellular and developmental events, some of which are as yet only partly understood. The number of fruit retained after petal fall gradually declines during the fruitlet abscission period, at the end of which the final percentage of fruit set is determined. At the tree level this is a highly competitive struggle for survival. The nature of the factors that limit fruit retention has been examined and discussed by Guardiola and coworkers (Garcia-Luis et al., 1988; Sanz et al., 1987). The fruit set problem is further complicated by the well-documented fact that in most cultivars, fruit set is better on leafy inflorescences than on purely generative, leafless inflorescences (Goldschmidt and Monselise, 1978; Jahn, 1973; Moss et al., 1972). This aspect has been thoroughly investigated and discussed by Erner (1989).

Although the evidence is still mostly indirect, it may be concluded that the level of carbohydrates is often a major factor limiting fruit set. As indicated by Garcia-Luis et al. (1988) and further analyzed by Bustan and Goldschmidt (1998), the demand for energy during the flowering and fruit set period may exceed the trees' capacity to supply carbohydrates from current photosynthesis and tree reserves. This is particularly true under conditions of profuse flowering and heavy initial fruit set. In accordance with this assumption, girdling during bloom is frequently used to improve fruit set (Monselise et al., 1972) and girdling of 'Shamouti' orange branches during the fruitlet abscission period increased final fruit set (Schaffer et al., 1985). However, girdling does not increase fruit set in all cases, indicating that shortage of carbohydrates is not the only factor responsible for flower and fruit abscission (Guardiola, 1997; Schaffer et al., 1985). In certain cultivars the carbohydrate limitation becomes apparent only during the late phase of fruitlet abscission, as fruitlets enlarge and require more photosynthate (Guardiola, 1997, Mehouachi et al., 1995). This supports the hypothesis that in cultivars with small-sized ovaries (e.g., 'Murcott'), the early stages of fruit development are not source-limited and do not benefit from an increased supply of photosynthate (Bustan et al., 1996).

The improved fruit set on leafy inflorescences has been attributed to the provision of photosynthate by inflorescence leaves (Goldschmidt and Monselise, 1978; Moss et al., 1972). Experimental evidence has shown, however, that purely generative inflorescences do not suffer from shortage of photosynthate (Erner, 1989). The fruit-set advantage of leafy inflorescences must, therefore, be explained by other mechanisms (Erner, 1989).

\section{FRUIT ENLARGEMENT}

Citrus fruits grow uninterruptedly from fruit set to harvest, as shown by detailed studies of fruit development (Bain, 1958; Monselise, 1986; Spiegel-Roy and Goldschmidt, 1996). Size is of foremost economic significance for marketing of fresh fruit, particularly with small, easy-peeling cultivars like 'Clementine'. Almost every possible agrotechnique has been tested in an attempt to increase fruit size.

There seems to be ample evidence supporting the existence of a carbohydrate source limitation to fruit enlargement. As mentioned above, both girdling and fruit thinning make more photosynthate available per fruit unit. Fruit thinning is a classical means for increasing fruit size at the expense of fruit number (Guardiola, 1988; SpiegelRoy and Goldschmidt, 1996). Girdling can also result in a meaningful increase in fruit size (Cohen 1981, 1984), although girdling during bloom, which increases fruit set, may eventually result in smaller fruit (Cohen, 1981). Synthetic auxins, alone or in combination with potassium, are also widely used to increase fruit size (Spiegel-Roy and Goldschmidt, 1996). However, synthetic auxins are effective only during early stages of fruit growth, whereas girdling increases fruit size whenever applied, even during late stages of fruit enlargement, as demonstrated with 'Marsh Seedless' grapefruit (Fishler et al., 1983). This indicates that carbohydrate limitation prevails throughout the period of fruit growth. A several-fold increase in fruit size may be obtained when girdling is combined with extreme fruit thinning (Fig. 2 ), showing that under normal orchard conditions there is a large, inexhaustible potential for fruit enlargement. 


\section{THE DILEMMA: HORMONES VS. CARBOHYDRATES}

Despite the extensive evidence presented in the previous sections, the regulatory role of carbohydrates in citrus productivity is still controversial. Many horticulturists maintain that in most instances hormones, rather than carbohydrates, are the critical factors.

The issue is complex, indeed. On the one hand, there are phenomena, such as preharvest fruit drop, where the problem is probably hormonal and a reduced level of auxins in the fruit pedicel is the limiting factor (Addicott, 1982). On the other hand, the combined effects of girdling and fruit thinning (Fig. 2) indicate that under regular cropping conditions carbohydrate supply is a major limiting factor for fruit enlargement. But then, other cases suggest that both hormones and carbohydrates are involved and the relationship between the two is not easily defined. The following are a few examples.

1.Parthenocarpic fruit set of seedy cultivars ('Clementine', 'Nova') is dependent to a large extent on the exogenous supply of gibberellins (Krezdorn, 1969; Monselise, 1979), which seem to replace the endogenous gibberellins produced by the ovary (Talon et al., 1992). However, girdling also effectively increases fruit set in most cultivars (Brosh and Monselise, 1977; Goren et al., 1995; Y. Erner, unpublished data). Moreover, in the seedy pummelo 'Chandler', girdling induces parthenocarpic fruit set, while gibberellins have no effect (Gefen, 1990). How then, do gibberellins and girdling interact in the promotion of fruit set? Is there a need for a hormonal stimulus combined with a requirement for a high level of energy?

2. Carbohydrate limitation apparently is the primary cause of fruitlet abscission; the resultant stress possibly leads to abscission via an ethylene signal, as with most other abscission systems (GonzalezCarranza et al., 1998). The link between low carbohydrate stress and ethylene has not been investigated so far.

3. The alternate bearing syndrome of numerous seedy Citrus reticulata cultivars certainly involves an impairment of principal nutritional and hormonal systems (Monselise and Goldschmidt, 1982). On one hand, the extreme depletion of carbohydrate reserves is of major significance (Goldschmidt and Golomb, 1982) and seems to be the critical factor underlying the collapse of 'Murcott' trees following an "on" year (Smith, 1976). But, on the other hand, the onset of the alternate bearing cycle might be related to an inability to form flowers on fruit-bearing twigs (Moss, 1981; Ogaki et al., 1963), presumably due to high levels of gibberellins produced by the seed (Plummer et al., 1989; Saidha et al., 1983) as in deciduous fruit trees ( Hoad, 1978; Pharis and King, 1985). Interestingly, some recently released seedless C. reticulata hybrid strains exhibit an extreme alternate bearing habit (Y. Kanonich, personal communication).

These examples may suffice to illustrate the complexity of regulatory interactions between carbohydrates and plant hormones. This is an area where further critical experiments are badly needed.

\section{LEVELS OF REGULATION}

Thus, carbohydrate levels probably participate in the regulation of plant metabolic and developmental events; however, how this control is exercised remains to be determined. The existence of numerous carbohydrate metabolites and a large number of enzyme systems makes it difficult to pinpoint the rate-limiting steps (e.g., Huber, 1989).

In addition to the coarse and fine control of enzyme activity, protein phosphorylation and dephosphorylation seem to play an increasingly significant role in the diurnal cycle of metabolic activities (Weiner et al., 1992)

A novel, exciting hypothesis, gaining strength and popularity, proposes that sugars themselves serve as signals in the modulation of gene expression (Koch et al., 1992; Sheen, 1990). Koch (1996) envisages different groups of genes that are up-regulated and downregulated by carbohydrate metabolites under varying conditions of carbohydrate supplies. The "on" and "off" " pendulum of alternatebearing citrus trees may fit very well into this scheme and may involve transcriptional control of gene expression. It is noteworthy, however, that feeding sucrose to detached potato and Arabidopsis leaves was sufficient to induce prominent changes in the gene expression of starch-degrading enzymes (Mita et al., 1995; Nakamura et al., 1991). This indicates that sugar-mediated gene expression may not be confined to extreme conditions and might, perhaps, be part of the regular, daily interplay of sources and sinks.

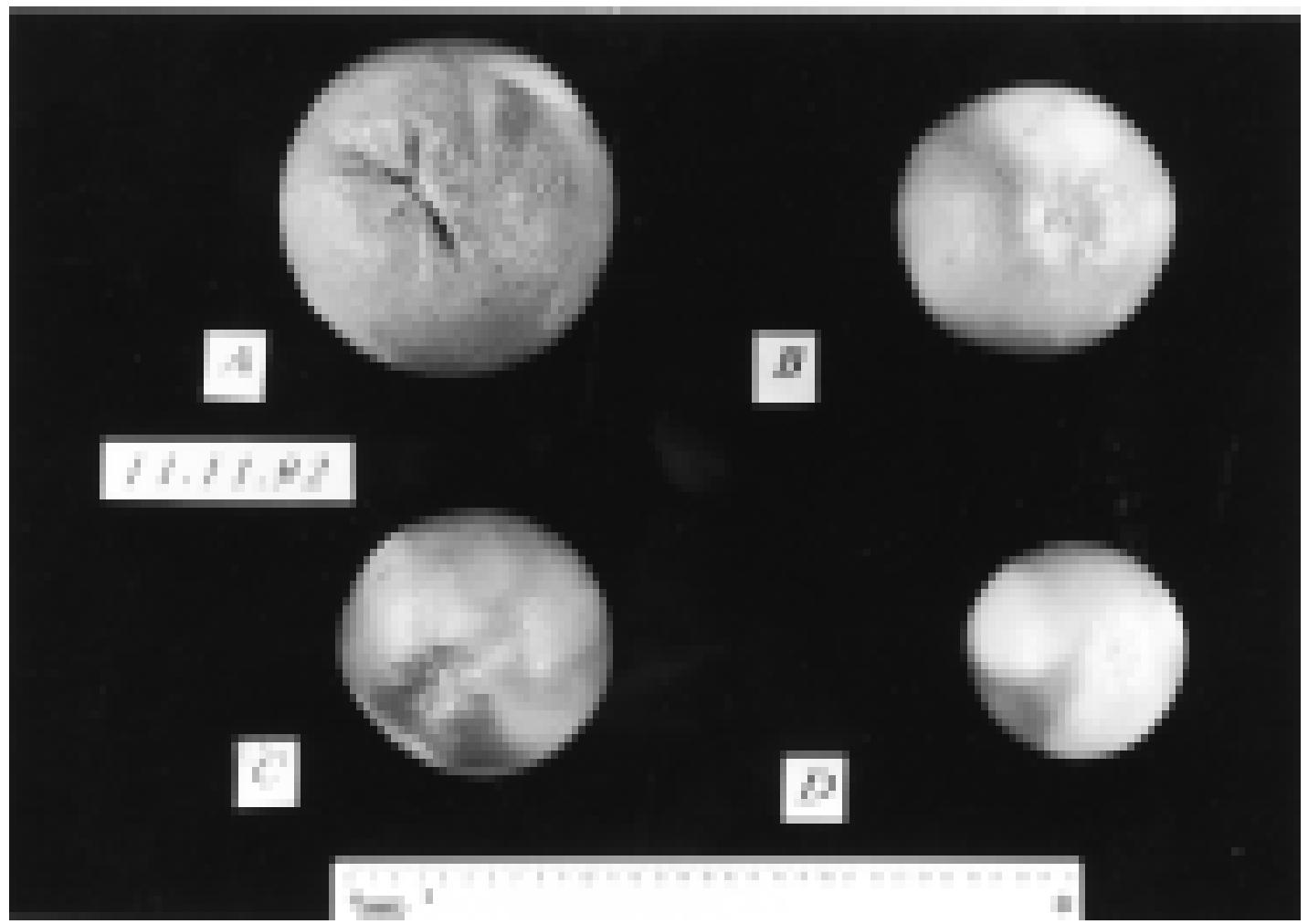

Fig. 2. Effects of (B) girdling, (C) fruit thinning, and (A) a combination of girdling and fruit thinning on fruit size of 'Marsh Seedless' grapefruit, as compared with fruit from (D) nontreated control trees. Average fruit fresh weights (g) were: (A) $705 \pm 76$; (B) $393 \pm 74 ;$ (C) $476 \pm 52$; (D) $330 \pm 34$. Trunk girdling and severe fruit thinning were performed on 1 July 1992 (A. Bustan, Y. Erner, and E.E. Goldschmidt, unpublished data). 
To what extent are molecular, genetic mechanisms involved in the quantitative control of productivity? How is molecular regulation linked to the classical nutritional and hormonal control systems? These intriguing questions will undoubtedly be in the focus of citrus productivity research in the forthcoming years.

\section{Literature Cited}

Addicott, F.T. 1982. Abscission. Univ. of California Press, Berkeley.

Akao, S., S. Tsukahara, H. Hisada, and S. Ono. 1981. Contribution of photosynthetic assimilates to development of flower and spring flush in Citrus unshiu Marc. J. Jpn. Soc. Hort. Sci. 50:1-9.

Albrigo, L.G. 1997. Influence of climate on pounds solids and acid production under Florida conditions, p. 98-99. In: S.H. Futch and W.J. Kender (eds.). Citrus flowering and fruiting short course. Citrus Res. Educ. Ctr., Lake Alfred, Fla.

Bain, J.M. 1958. Morphology, anatomical, and physiological changes in the developing fruit of the valencia orange, Citrus sinensis (L.) Osbeck. Austral. J. Bot. 6:1-28.

Brosh, P. and S.P. Monselise. 1977. Increasing yields of 'Topaz' mandarin by gibberellin and girdling in the presence of 'Minneola' pollinizers. Scientia Hort. 7:369-372.

Bustan, A., Y. Erner, and E.E. Goldschmidt. 1996. Carbohydrate supply and demand during fruit development in relation to productivity of grapefruit and 'Murcott' mandarin. Acta Hort. 416:81-88.

Bustan, A. and E.E. Goldschmidt. 1998. Estimating the cost of flowering in a grapefruit tree. Plant Cell Environ. 21:217-224.

Chabot, B.F. and D.J. Hicks. 1982. The ecology of leaf life spans. Annu. Rev. Ecol. Syst. 13:229-259.

Cohen, A. 1981. Recent developments in girdling of citrus trees. Proc. Intl. Soc. Citricult. 196-199.

Cohen, A. 1984. Citrus fruit enlargement by means of summer girdling. J. Hort. Sci. 59:119-125.

Cutting, J.G.M.Y. and M.C. Lyne. 1993. Girdling and the reduction in shoot xylem sap concentrations of cytokinins and gibberellins in peach. J. Hort. Sci. 68:619-626.

Dann, I.R., P.H. Jerie, and D.J. Chalmers. 1985. Short-term changes in cambial growth and endogenous IAA concentrations in relation to phloem girdling of peach Prunus persica (L.) Batsch. Austral. J. Plant. Physiol. 12:395-402.

Erner, Y. 1989. Citrus fruit set: Carbohydrate, hormone and leaf mineral relationships, p. 233-242. In: C.J. Wright (ed.). Manipulation of fruiting. Butterworth, London

Fishler, M., E.E. Goldschmidt, and S.P. Monselise. 1983. Leaf area and fruit size in girdled grapefruit branches. J. Amer. Soc. Hort. Sci. 108:218-221.

Garcia-Luis, A., F. Fornes, and J.L. Guardiola. 1995. Leaf carbohydrates and flower formation in Citrus. J. Amer. Soc. Hort. Sci. 120:222-227.

Garcia-Luis, A., F. Fornes, A. Sanz, and J.L. Guardiola. 1988. The regulation of flowering and fruit set in Citrus: Relationship with carbohydrate levels. Israel J. Bot. 37:189-201.

Gefen, D. 1990. Increase of pummelo 'Chandler' productivity, Mesilot orchard (in Hebrew). Alon Hanotea 44:576-578.

Goldschmidt, E.E., N. Aschkenazi, Y. Herzano, A.A. Schaffer, and S.P. Monselise. 1985. A role for carbohydrate levels in the control of flowering in citrus. Scientia Hort. 26:159-166.

Goldschmidt, E.E. and A. Golomb. 1982. The carbohydrate balance of alternate-bearing citrus trees and the significance of reserves for flowering and fruiting. J. Amer. Soc. Hort. Sci. 107:206-208.

Goldschmidt, E.E. and K.E. Koch. 1996. Citrus, p. 797-823. In: E. Zamski and A. A Schaffer (eds.). Photoassimilate distribution in plants and crops. Marcel Dekker, New York.

Goldschmidt, E.E. and S.P. Monselise. 1978. Physiological assumptions toward the development of a citrus fruiting model. Proc. Intl. Soc. Citricult. 2:668-672.

Goldschmidt, E.E., M. Tamim, and R. Goren. 1997. Gibberellins and flowering in citrus and other fruit trees: A critical analysis. Acta Hort. 463:201-208.

Gonzalez-Carranza, Z.H., E. Lozoya-Gloria, and J.A. Roberts. 1998. Recent developments in abscission: Shedding light on the shedding process. Trends Plant Sci. 3:10-14.

Gonzalez-Ferrer, J., M. Agusti, and J.L. Guardiola. 1984. Fruiting pattern and retranslocation of reserves in the Navelate and Washington navel oranges. Proc. Intl. Soc. Citricult. 1:194-200.

Goren, R., M. Huberman, and J. Riov. 1995. Effects of gibberellin and girdling on the yield of 'Nova' (Clementine $\mathrm{x}$ 'Orlando' tangelo) and 'Niva' ('Valencia' x 'Wilking'). Proc. Intl. Soc. Citricult. 1992, 1:493-499.

Guardiola, J.L. 1988. Factors limiting productivity in citrus: A physiological approach. Proc. Intl. Soc. Citricult. 1:381-394.

Guardiola, J.L. 1997. Competition for carbohydrates and fruit set, p. 43-61. In:
S.H. Futch and W.J. Kender (eds). Citrus flowering and fruiting short course. Citrus Res. and Educ. Ctr., Lake Alfred, Fla.

Hilgeman. R.H., J.A. Dunlap, and G.C. Sharples. 1967. Effect of time of harvest of Valencia oranges on leaf carbohydrate content and subsequent set of fruit. Proc. Amer. Soc. Hort. Sci. 90:110-116.

Hoad, G.V. 1978. The role of seed derived hormones in the control of flowering in apple. Acta Hort. 80:93-103.

Huber, S.C. 1989. Biochemical mechanism for regulation of sucrose accumulation in leaves during photosynthesis. Plant Physiol. 91:656-662.

Idso, S.B. and B.A. Kimball. 1994. Effects of atmospheric $\mathrm{CO}_{2}$ enrichment on regrowth of sour orange trees (Citrus aurantium: Rutacea) after coppicing. Amer. J. Bot. 81:843-846.

Jahn, O.L. 1973. Inflorescence types and fruiting patterns in Hamlin and Valencia oranges and Marsh grapefruit. Amer. J. Bot. 60:663-670.

Jones, W.W. and M.L. Steinacker. 1951. Seasonal changes in concentration of sugars and starch in leaves and twigs of citrus trees. Proc. Amer. Soc. Hort. Sci. $58: 1-4$.

Koch, K.E. 1996. Carbohydrate-modulated gene expression in plants. Annu. Rev. Plant Physiol. Plant Mol. Biol. 47:509-540.

Koch, K.E., K.D. Nolte, E.R. Duke, D.R. McCarthy, and W.T. Avigne. 1992 Sugar levels modulate differential expression of maize sucrose synthase genes. Plant Cell 4:59-69.

Krezdorn, A.H. 1969. The use of growth regulators to improve fruit set in citrus. Proc. 1st. Intl. Citrus Symp., Riverside, Ca. p. 1113-1119.

Kriedemann, P.E. 1971. Crop energetics and horticulture. HortScience 6:432438.

Larcher, W. 1980. Physiological plant ecology, 2nd ed. Springer-Verlag, New York.

Loescher, W.H., T. McCamant, and J.D. Keller. 1990. Carbohydrate reserves, translocation and storage in woody plant roots. HortScience 25:274-281.

Mehouachi, J., D. Serna, S. Zaragoza, M. Agusti, M. Talon, and E. PrimoMillo. 1995. Defoliation increases fruit abscission and reduces carbohydrate levels in developing fruits and woody tissues of Citrus unshiu. Plant Sci. 107:189-197.

Mita, S., K. Suzuki-Fujii, and K. Nakamara. 1995. Sugar-inducible expression of a gene for $\beta$-amylase in Arabidopsis thaliana. Plant Physiol. 107:895904.

Monselise, S.P. 1979. The use of growth regulators in citriculture. A review. Scientia Hort. 11:151-162.

Monselise, S.P. 1986. Citrus, p. 87-108. In: S.P. Monselise (ed.). Handbook of fruit set and development. CRC Press, Boca Raton, Fla.

Monselise, S.P. and E.E. Goldschmidt. 1982. Alternate bearing in fruit trees. Hort. Rev. 4:128-173.

Monselise S.P., R. Goren, and I. Wallerstein. 1972. Girdling effect on orange fruit set and young fruit abscission. HortScience 7:514-515.

Moss, G.I., K.B. Bevington, P.T. Gallasch, and I.R. El-Zeftawi. 1981. Alternate cropping of Valencia oranges. Dept Agr., New South Wales Sci. Bul. 88.

Moss, G.I. B.T. Steer, and P.E. Kriedemann. 1972. The regulatory role of inflorescence leaves in fruit setting in sweet orange (Citrus sinensis). Physiol. Plant. 27:432-438.

Nakamura K., M. Ohto, N. Yoshida, and K. Nakamura, 1991. Sucrose-induced accumulation of $\beta$-amylase occurs concomitantly with the accumulation of starch and sporamin in leaf-petiole cuttings of sweet potato. Plant Physiol. 96:902-909.

Ogaki, C., K. Fugita, and H. Ito. 1963. Investigations on the cause and control of alternate bearing of Unshiu orange trees. III. Effects of fruiting in the previous season on flower formation. J. Hort. Assn. Jpn. 32:13-19.

Pharis, R.P. and R.W. King. 1985. Gibberellins and reproductive development in seed Plants. Annu. Rev. Plant Physiol. 36:517-568.

Plummer, J.A., M.G. Mullins, J.H. Vine, and R.P. Pharis. 1989. The role of endogenous hormones in shoot emergence and abscission in alternate bearing valencia orange trees. Acta. Hort. 239:341-344.

Saidha, T., E.E. Goldschmidt, and S.P. Monselise. 1983. Endogenous growth regulators in tracheal sap of citrus. HortScience 18:231-232.

Sanz, A., C. Monerri, J. Gonzalez-Ferrer, and J.L. Guardiola. 1987. Changes in carbohydrates and mineral elements in citrus leaves during flowering and fruit set. Physiol. Plant. 69:93-98.

Schaffer, A.A., E.E. Goldschmidt, R. Goren, and D. Galili. 1985. Fruit set and carbohydrate status in alternate and non-alternate bearing citrus cultivars. J. Amer. Soc. Hort. Sci. 110:574-578.

Schaffer, B., A.W. Whiley, and J.H. Crane. 1994. Mango, p. 165-197. In: B. Schaffer and P.C. Anderson (eds.). Handbook of envirommental physiology of fruit crops, vol. 2, CRC Press, Boca Raton, Fla.

Scholefield, P.B., M. Sedgley, and D. McE. Alexander. 1985. Carbohydrate cycling in relation to shoot growth, floral initiation and development and yield in the avocado. Scientia. Hort. 25:99-110.

Sheen, J. 1990. Metabolic repression of transcription in higher plants. Plant Cell 2:1027-1038.

Shimizu, T., H. Torikata, and S. Torii. 1978. Studies on the effect of crop load 


\section{Colloquium}

on the composition of Satsuma mandarin trees. V. Analysis of production processes of bearing and non-bearing trees on the carbohydrate economy. J. Jpn. Soc. Hort. Sci. 46:465-478.

Smith, P. 1976. Collapse of 'Murcott' tangerine trees. J. Amer. Soc. Hort. Sci. 101:23-25.

Spiegel-Roy, P. and E.E. Goldshmidt. 1996. Biology of citrus. Cambridge Univ. Press, Cambridge, U.K.

Syvertsen. J.P. and J. Lloyd. 1994. Citrus, p. 65-99. In: B. Schaffer and P.C. Anderson (eds.). Handbook of environmental physiology of fruit crops, vol. 2. CRC Press, Boca Raton, Fla.

Syversten, J.P., J. Lloyd, C. McConchie, P.E. Kriedemann, and G.D. Farquhar. 1995. On the relationship between leaf anatomy and $\mathrm{CO}_{2}$ diffusion through the mesophyll of hypostomatous leaves. Plant Cell Environ. 18:149-157.

Syversten, J.P., M.L. Smith, J. Lloyd, and G.D. Farquhar. 1997. Net carbon dioxide assimilation. carbon isotope discrimination, growth, and water use efficiency of Citrus trees in response to nitrogen status. J. Amer. Soc. Hort.
Sci. 122:226-232.

Talon, M., L. Zacarias, and E. Primo-Millo. 1992. Gibberellins and parthenocarpic ability in developing ovaries of seedless mandarins. Plant Physiol. 99:1575-1581.

Wallerstein, I., R. Goren, and S.P. Monselise. 1973. Seasonal changes in giberellin-like substances of Shamouti orange [Citrus sinensis (L.) Osbeck] trees in relation to ringing. J. Hort. Sci. 48:75-82.

Weiner, H., R.W. McMichael, Jr., and S.C. Huber. 1992. Identification of factors regulating the phosphorylation status of sucrose-phosphate synthase in vivo. Plant Physiol. 99:1435-1442.

Whiley, A.W. and B. Schaffer. 1994. Avocado, p. 3-35. In: B. Schaffer and P.C. Anderson (eds.). Handbook of environmental physiology of fruit crops, vol. 2. CRC Press, Boca Raton, Fla.

Whiley, A.W., C. Searle, B. Schaffer, and B.N. Wolstenholme. 1999. Cool orchard temperatures or growing trees in containers can inhibit leaf gas exchange of avocado and mango. J. Amer. Soc. Hort. Sci. 124: 46-51. 